\title{
PENILAIAN MUTU PERGURUAN TINGGI DENGAN PERSPEKTIF BALANCE SCORECARD DI IAIN SYAIKH ABDURAHMAN SIDDIK BANGKA BELITUNG
}

\author{
Marheni1 \\ IAIN Syaikh Abdurrahman Siddik Bangka Belitung \\ marheni.utama@gmail.com
}

\begin{abstract}
The purpose of this study is to assess the quality of tertiary institutions from four perspectives, namely financial perspective, customer perspective, internal business process perspective, learning and growth perspective for IAIN Sheikh Abdurahman Siddik Bangka Belitung. Based on the discussion and analysis of the data it can be concluded that 1) based on a financial perspective shows that the growth of assets and leverage shows that there is a tendency for growth; 2) Based on the measurement of the Growth and Learning perspective (Learning and Growth) explained that workers, lecturers and employees have felt the management system at the university is good; 3) Based on the measurement of the Internal Business (Internal Business Process), universities make efforts to improve the quality of students; 4) Based on the perspective of the customer (Customer) the results show that students feel the service provided is good.
\end{abstract}

Keywords : Evaluation, Quality, Balance Scorecard

\begin{abstract}
ABSTRAK
Tujuan penelitian ini adalah menilai mutu perguruan tinggi dilihat dari empat perspektif yaitu perspektif keuangan, perspektif pelanggan, perspektif proses bisnis internal, perspektif pembelajaran dan pertumbuhan bagi IAIN Syaikh Abdurahman Siddik Bangka Belitung. Berdasarkan pembahasan dan analisis data disimpulkan bahwa 1) berdasarkan perspektif keuangan menunjukkan bahwa pertumbuhan aset dan leverage menunjukkan adanya perkembangan yang cenderung meningkat; 2) Berdasarkan pengukuran perspektif Pertumbuhan dan Pembelajaran (Learning and Growth) dijelaskan bahwa pekerja, dosen dan karyawan sudah merasakan sistem pengelolaan di universitas sudah baik; 3) Berdasarkan pengukuran Bisnis Internal (Internal Bussiness Process), perguruan tinggi melakukan upaya untuk meningkatkan mutu mahasiwa; 4) Berdasarkan perspektif Pelanggan (Customer) berupa hasilnya menunjukkan bahwa mahasiswa merasakan pelayanan yang diberikan baik.
\end{abstract}

Kata Kunci : Penilaian, mutu, Balance Scorecard 


\section{Pendahuluan}

Pendidikan sangat diperlukan dalam mengembangkan sumber daya manusia. Untuk menghasilkan SDM yang berkualitas, lembaga pendidikan memiliki peranan penting. Ada banyak lembaga pendidikan mulai dari pendidikan bagi anak usia dini hingga bagi mahasiswa. Salah satu lembaga pendidikan adalah perguruan tinggi yang mengalami dinamika dan akselerasi yang semakin berkembang. Selain perguruan tinggi negeri, perguruan tinggi swasta yang semakin banyak berdiri di Indonesia. Tetapi saat ini, PTS masih dianggap perguruan tinggi alternatif kedua yang memiliki kualitas relatif berbeda dibandingkan PTN. Oleh karena itu, pengelola PTS memiliki tantangan ke depan untuk meningkatkan mutu terutama dalam era globalisasi yang penuh tekanan persaingan dan meningkatkan mutu dengan penilaian kinerja. Meskipun demikian PTN tetap harus meningkatkan kinerja dari berbagai aspek untuk menciptakan profesionalitas dan menghasilkan lulusan yang kompeten. Adanya pergeseran yang menyebabkan setiap perguruan tinggi pada orientasi persaingan dalam level nasional ${ }^{1}$.

Perubahan sangat besar dalam menghadapi lingkungan yang dinamis maka organisasi memerlukan pertimbangan terbaik yang untuk kelangsungan organisasi di masa mendatang. Oleh karena itu penilaian mutu organisasi yang diukur dengan kinerja dalam memenuhi berbagai pihak kepentingan yang diukur dengan ukuran strategis, ukuran hasil, keuangan dan non keuangan serta internal dan eksternal. ${ }^{2}$ Salah satu perubahan organisasi yang dialami adalah perguruan tinggi di Indonesia.

Perkembagan perguruan tinggi di Indonesia akan semakin marak dan semakin banyak perguruan tinggi swasta yang bersifat legal jika terpenuhi enam syarat yaitu akta pendirian, ijin pendirian, penyelesaian laporan perguruan tinggi, tidak ada pembelajaran jarak jauh, ada akreditasi dari BAN PT dan tidak memiliki konflik internal. Adanya fenomena perguruan tinggi tersebut menyebabkan penilaian kinerja perguruan tinggi harus dilakukan untuk menilai mutu perguruan tinggi. Pengukuran kinerja merupakan usaha dari manajemen yang dilakukan

\footnotetext{
${ }^{1}$ Hamid, Darmasi. 2013. Metode Penelitian Pendidikan dan social. Bandung: Alfabeta.hal.35

2 Anthony, Robert N. dan Govindarajan, Vijay. 2005. Buku 2 Management Control System. Jakarta. Salemba Empat.hal.65
} 
secara periodik untuk menentukan strategi yang tepat dalam organisasi sehingga mencapai keberhasilan tujuan. Pendekatan dalam pengukuran kinerja ditekankan pada aspek keuangan dan non keuangan sehingga dalam menghadapi lingkungan usaha yang dinamis membuat perguruan tinggi akan melakukan pengukuran kinerja untuk mengukur mutu dari organisasi.

Penilaian mutu perguruan tinggi dilakukan dengan menetapkan jaminan mutu dari seluruh perguruan tinggi yang dikenal sebagai sistem penjaminan mutu baik internal dan eksternal. Penilaian mutu perguruan tinggi juga dinilai dengan kinerja perguruan tinggi dengan berbagai pendekatan salah satunya adalah pendekatan Balance Scorecard. Balance Scorecard memberikan informasi untuk mengevaluasi apakah proses kerja yang dilakukan organisasi itu sudah berjalan sesuai dengan yang diharapkan. Balance Scorecard merupakan konsep pengukuran kinerja dengan empat perspektif antara lain perspektif finansial, perspektif customer, perspektif proses bisnis internal, serta perspektif pertumbuhan dan pembelajaran. Dasar dari Balance Scorecard itu merupakan strategi dan tujuan yang ingin dicapai oleh suatu instansi baik instansi pemerintah maupun swasta yang kemudian akan dimonitor secara berkesinambungan. Al-Hosaini dan Sofian (2015) meneliti dengan judul Balanced Scorecard Framework in Higher Education. ${ }^{3}$ Hasil penelitian menemukan efektivitas BSC dalam organisasi dapat digunakan untuk mengukur kinerja.

IAIN Syaikh Abdurrahman Siddik merupakan Perguruan Tinggi Islam Negeri yang ada di Bangka Belitung. IAIN Syaikh Abdurrahman Siddik Bangka Belitung beralih status pada tanggal 7 April 2018 yang sebelumnya STAIN. Dengan adanya alih status ini, tentunya banyak hal yang harus dikembangkan oleh manajemen kampus untuk meningkatkan mutu perguruan tinggi. Perlu adanya komitmen dan kerja sama yang baik dari berbagai pihak, mulai dari fakultas, unit-unit yang ada hingga pimpinan. Penilaian kinerja menjadi hal wajib untuk dilakukan agar dapat mengetahui progress pencapaian tujuan perguruan tinggi.

Tujuan penelitian ini yaitu untuk melakukan penilaian mutu perguruan tinggi berdasarkan pendekatan balance scorecard dengan empat perspektif yaitu

\footnotetext{
${ }^{3}$ Al-Hosaini, Fahmi Fadhl dan Sofian, Saudah. 2015. Balanced Scorecard Framework in Higher Education. International Review of Management and Marketing Vol. 5, No.1
} 
perspektif keuangan, perspektif pelanggan, perspektif proses bisnis internal dan perspektif pembelajaran dan pertumbuhan di IAIN Syaikh Abdurrahman Siddik Bangka Belitung. Penelitian ini bermanfaat antara lain berkontribusi bagi penemuan penelitian yang dihadapi dan berkontribusi untuk keputusan pengambilan keputusan tentang strategi demi kesuksesan lembaga penelitian yaitu khususnya IAIN Syaikh Abdurahman Siddik Bangka Belitung. Sedangkan bagi penelitian selanjutnya akan dijadikan referensi dengan penilaian kinerja berbasis Balance Scorecard.

\section{Balance Scorecard Sebagai Konsep Pengukuran Kinerja}

Pengukuran kinerja dengan menggunakan konsep Balance Scorecard atau BSC adalah alat manajemen yang didesain untuk melihat kemampuan perusahaan dalam mengukur kinerja secara berkesinambungan baik aspek keuangan dan nonkeuangan. Balance Scorecard diperkenalkan oleh Robert Kaplan pada tahun 1992 yang merupakan konsep pengukuran kinerja didasarkan dari pendekatan efektif yang seimbang dalam mengukur kinerja dan strategi perusahaan metode pengukuran kinerja dengan Balance Scorecard itu mencerminkan pemikiran baru dalam kompetitif dan efektivitas organisasi dengan mengukur 4 perspektif yang menjadi komponen utama. ${ }^{4}$

Empat perspektif antara antara lain pengukuran dengan empat perspektif akan menjadikan alat ukur yang digunakan untuk menilai kinerja perusahaan baik keuangan maupun non keuangan. Beberapa keunggulan Balance Scorecard antara lain komprehensif, dimana Balance Scorecard dapat memperluas perspektif dalam perencanaan strategi yaitu tidak terbatas pada strategi keuangan tetapi juga pada pelanggan, proses bisnis internal, pembelajaran dan pertumbuhan. Koheren, dimana Balance Scorecard dapat membangun hubungan sebab akibat dengan berbagai sasaran strategi sehingga akan dihasilkan perencanaan yang tepat. Seimbang, dengan memberikan keseimbangan dalam empat perspektif baik jangka pendek dan jangka panjang yang difokuskan pada faktor internal dan eksternal.

Adanya keseimbangan dalam BSC juga mencerminkan selarasnya scorecard personal dengan scorecard organisasi sehingga personal dalam organisasi akan

\footnotetext{
${ }^{4}$ Kaplan, Robert S. and D.P Norton. 2000. Balanced Scorecard: Menerapkan Strategi Menjadi Aksi. Alih Bahasa: Peter R, Yosi Pasla . Jakarta. Erlangga. Hal.121
} 
memiliki tanggung jawab untuk memajukan organisasi empat terukur pemikiran bahwa perspektif dapat diukur dengan keyakinan 'if you can do it we can manage it if we can manage it we can achieve it" ${ }^{5}$, di mana sasaran strategi yang akan diukur pada perspektif pelanggan bisnis internal dan pembelajaran pertumbuhan. Sifat Balance Scorecard itu dapat memperluas perspektif secara komprehensif mewajibkan personal untuk sebab-akibat dan menyeimbangkan sasaran strategi dalam perencanaan yang seimbang sehingga memudahkan pencapaian sasaran strategi yang dapat terukur. Pengukuran kinerja yang merupakan bagian dari pengendalian manajemen akan mengimplikasikan keputusan perencanaan dan penilaian kinerja pegawai serta operasional. Penilaian kinerja untuk mengetahui pencapaian tujuan penilaian prestasi penilaian manajemen dan memprediksi keuntungan-keuntungan di masa mendatang. Berdasarkan beberapa penelitian dapat dinyatakan bahwa Balance Scorecard merupakan alat ukuran sistem manajemen untuk kinerja dengan beberapa perspektif sehingga menemukan strategi target kerja dan solusi permasalahan manajemen Adapun 4 perspektif Balance Scorecard dijelaskan Gambar 1 berikut:

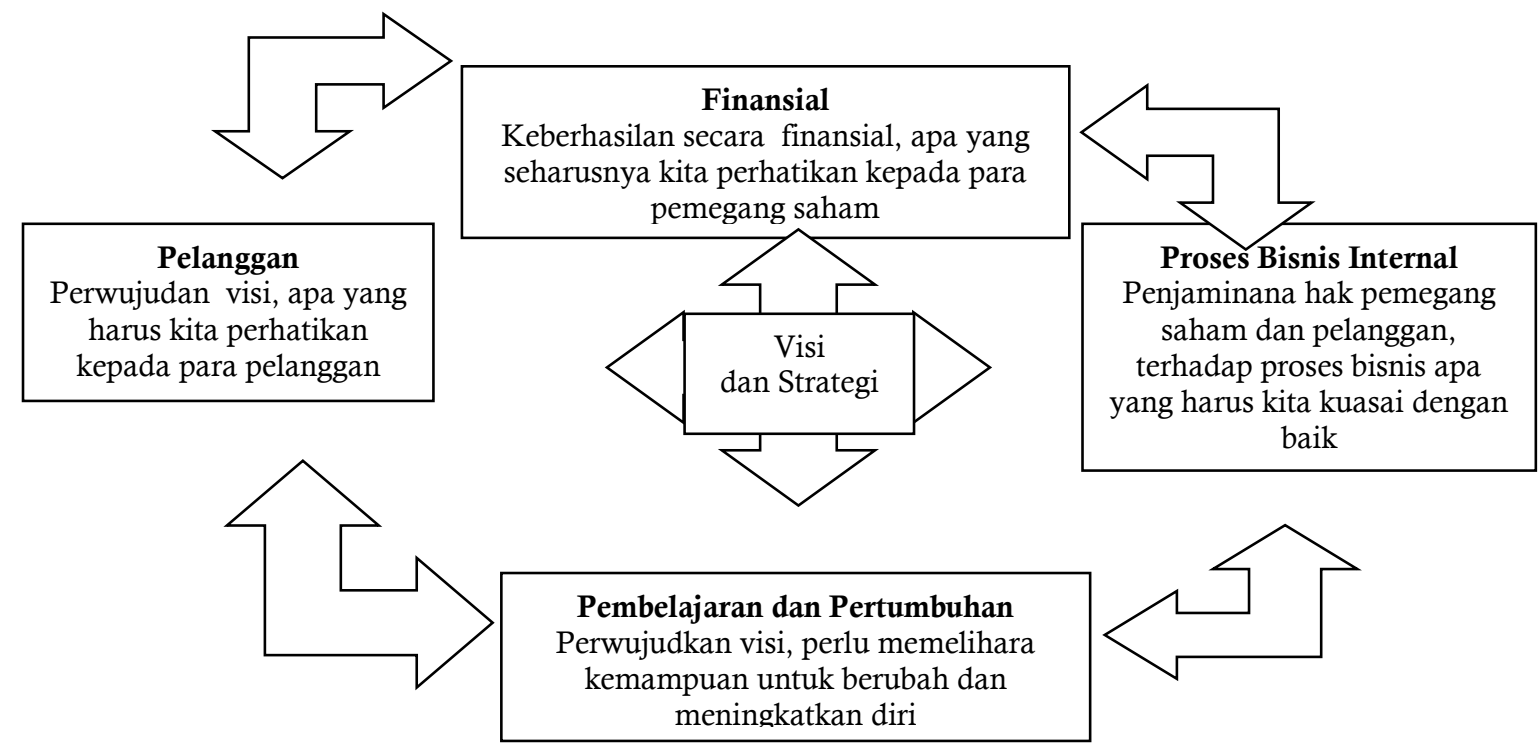

Gambar 1. Balanced Scorecard sebagai suatu sistem manajemen Kinerja ${ }^{6}$

Balanced Scorecard terdiri dari empat perspektif, yaitu: finansial, pelanggan, proses bisnis internal, dan pembelajaran dan pertumbuhan pada (Gambar 2).

\footnotetext{
${ }^{5}$ Ibid, hal.122

${ }^{6}$ Gaspersz, Vincent. 2014. Production Planning and Inventory Control, Jakarta: Erlangga
} 
PERPEKTIF FINANSIAL

PERSPEKTIF PELANGGAN

PERSPEKTIF PROSES BISNIS

INTERNAL

PERSPEKTIF PEMBELAJARAN

DAN PERTUMBUHAN

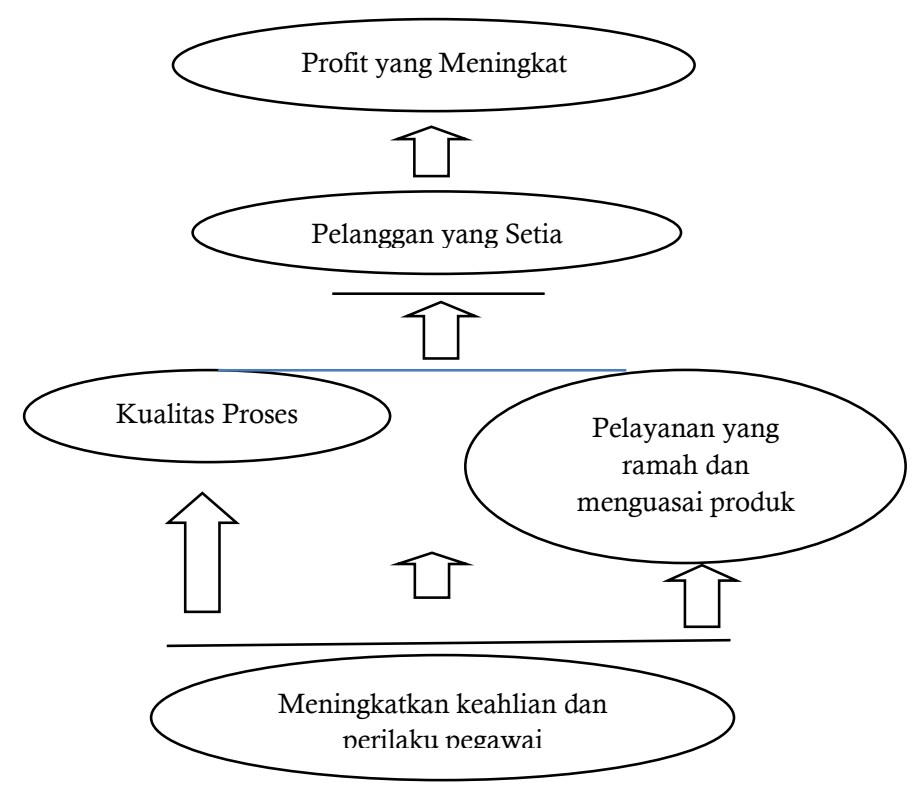

Gambar 2. Gambar Empat perspektif BSC7

Kaplan dan Norton menjelaskan bahwa if can measure it you can manage it, di mana hal itu merupakan pengukuran terhadap semua aktivitas yang dilakukan baik aktivitas secara kualitatif dan aktivitas secara kuantitatif dalam pengukuran kinerja. ${ }^{8}$ Sistem manajemen kinerja Balanced Scorecard digunakan untuk mengukur kinerja organisasi bisnis. Menurut Anderson dan Clancy pengukuran kinerja adalah:

"feedback from the accountant to management that provides informantion about how well the actions represent the plans; it also identifies where managers may need to make corrections or adjustments in future planning and controlling activities." 9

Pengukuran kinerja merupakan tindakan pengukuran yang dilakukan dengan berbagai aktivitas yang masuk dalam rantai nilai perusahaan atau organisasi. ${ }^{10}$ Hasil pengukuran itu akan digunakan sebagai umpan balik untuk memperoleh informasi dalam pelaksanaan suatu perencanaan dan titik temu dari organisasi untuk menyesuaikan aktivitas perencanaan dan pengendalian. Pengukuran kinerja

\footnotetext{
${ }^{7}$ Luis, Suwardi. 2010. Step by Step in Cascading Balanced.PT. Gramedia Pustaka Utama. Jakarta. Hal.111

${ }^{8}$ Kaplan, Robert S. and D.P Norton. 2000. Balanced Scorecard: Menerapkan Strategi Menjadi Aksi. Alih Bahasa: Peter R, Yosi Pasla . Jakarta. Erlangga. Hal.124

${ }^{9}$ Mulyadi. 2015. Akuntansi Biaya, Edisi 5. Yogyakarta : Sekolah Tinggi Ilmu. Manajemen YKPN. hal.122

${ }^{10}$ Ibid, hal.122
} 
dalam sistem pengendalian manajemen yang digunakan untuk pertimbangan dalam perencanaan dan pengambilan keputusan merupakan sarana untuk mengetahui ketercapaian tujuan penilaian bisnis dan keberhasilan perusahaan di masa mendatang berdasarkan beberapa bagian.

Ada modifikasi keseimbangan pada perspektif finansial dan perspektif pelanggan dalam organisasi sehingga BSC digunakan. Hal ini dikarenakan BSC memiliki beberapa penyesuaian. Pertama, adanya fokus sektor publik, yaitu masyarakat dan sektor bisnis merupakan pelanggan dan pemegang saham. Kedua, tujuan organisasi publik itu memaksimalkan keuangan tetapi menyeimbangkan pertanggungjawaban keuangan dengan pelayanan berbagai pihak yang berkepentingan. Ketiga, definisi ukuran dalam perspektif pelanggan membutuhkan tingkat kepedulian yang tinggi dan konsekuensi dalam kepengurusan organisasi serta adanya rencana yang sesuai dengan hasil strategi yang diinginkan. ${ }^{11}$ Kaplan dan Norton (2000) menjelaskan bahwa:

"Balance scorecard adalah metode alternatif yang digunakan perusahaan untuk mengukur kinerja perusahaan secara lebih komprehensif, tidak hanya terbatas pada kinerja keuangan, namun meluas ke kinerja non keuangan, seperti perspektif pelanggan, proses bisnis internal, serta pembelajaran dan pertumbuhan". 12

Balanced scorecard adalah suatu pendekatan pengukuran kinerja dengan melakukan penilaian terhadap empat perspektif yang saling berhubungan untuk menentukan strategi yang akan dicapai sesuai tujuan yang diharapkan dalam jangka panjang. BSC dilakukan 4 perspektif yaitu: 1) Perspektif Keuangan: strategi pertumbuhan dan profitabilitas; 2) Perspektif Pelanggan: strategi untuk menciptakan nilai dan diferensiasi dari kacamata pelanggan; 3) Perspektif Proses Bisnis Internal: prioritas strategi atas berbagai proses bisnis yang menciptakan kepuasan pelanggan dan 4) perspektif pembelajaran dan pertumbuhan: berbagai prioritas untuk menciptakan lingkungan yang kondusif bagi perubahan, inovasi dan pertumbuhan secara organisasional.

\footnotetext{
${ }^{11}$ Luis, Suwardi. 2010. Step by Step in Cascading Balanced.PT. Gramedia Pustaka Utama. Jakarta. Hal.111

${ }^{12}$ Mulyadi. 2015. Akuntansi Biaya, Edisi 5. Yogyakarta : Sekolah Tinggi Ilmu. Manajemen YKPN. hal.124
} 


\section{Metode penelitian}

Penelitian ini merupakan penelitian deskriptif, yaitu untuk mendeskripsikan informasi (sesuai dengan variabel-variabel), mencatatkan hasil, menganalisis, dan menginterprestasikan kondisi yang sedang terjadi. Penelitian ini dilakukan pada IAIN Syaikh Abdurrahman Siddik Bangka Belitung. Metode pengumpulan data antara lain:

a. Perspektif pelanggan data dengan mengetahui jumlah mahasiswa dan kepuasan mahasiswa (Customer Care dan Customer Value Proposition).

b. Perspektif finansial dalam penelitian ini menggunakan metode pengumpulan data dengan pencatatan dan mengkalkulasi data laporan keuangan dari bagian keuangan yaitu laporan neraca tahun 2017-2018.

c. Perspektif proses bisnis internal dalam penelitian ini menggunakan metode pengumpulan data dengan Minimize Error Rate and Rework (MERR).

d. Perspektif pembelajaran dan pertumbuhan dengan pencatatan dan mengkalkulasi ukuran generik kepuasan pekerja, dosen dan karyawan.

Metode analisis data dengan empat (4) perspektif dalam penelitian ini sebagai berikut:

a. Perspektif Keuangan

1) Pertumbuhan Aset

$$
\text { GROWTH }=\frac{\text { Total } \text { Aktiva }_{t}-\text { Total Aktiva }}{t-1}
$$

\section{2) Leverage}

Leverage yaitu rasio yang digunakan untuk mengukur sampai berapa jauh aktiva lembaga penyiaran dibiayai dengan hutang.

1) Rasio Debt to Total Asset

Debt to Total Assets $=$ Total Debt

Total Assets 
b. Perspektif Pelanggan

1) Customer Care, yaitu:

a) Customer Retention = Jumlah Mahasiswa Lama x 100\%

Jumlah Mahasiswa

b) Customer Acquisition = Jumlah Mahasiswa Baru x 100\%

Jumlah Mahasiswa

2) Customer Value Proposition yaitu menaksir tingkat kepuasan mahasiswa yang terkait dengan kriteria spesifik yang harus disajikan oleh lembaga IAIN Syaikh Abdurrahman Siddik Bangka Belitung yang meliputi atribut jasa, hubungan dengan mahasiswa, kesan dan reputasi dan kepuasan mahasiswa. Jadi untuk menentukan kategori (customer value preposition) kepuasan pelanggan secara keseluruhan.

c. Perspektif Proses Bisnis Internal

Internal Bussiness Process dilakukan dengan mengukur mutu, waktu tanggap, biaya, dan pengenalan program baru perguruan tinggi sebagai upaya untuk meningkatkan mutu pendidikan.

d. Proses pembelajaran dan pertumbuhan

Proses pembelajaran dan pertumbuhan diukur dengan ukuran generik kepuasan pekerja, dosen dan karyawan merasakan sistem pengelolaan di pergurun tinggi sudah baik.

\section{Karakteristik responden}

Karakteristik responden dijelaskan dengan jenis kelamin dan usia responden. Responden merupakan mahasiswa di IAIN Syaikh Abdurrahman Siddik Bangka Belitung. Berdasarkan penelitian yang telah dilakukan di IAIN Syaikh Abdurahman Siddik Bangka Belitung, maka dapat diketahui karakteristik responden seperti berikut.

a. Jenis Kelamin

Karakteristik responden berdasarkan jenis kelamin dapat dilihat pada Tabel 1 berikut. 
Tabel 1. Karakteristik Responden Berdasarkan Jenis Kelamin Pada IAIN Syaikh Abdurahman Siddik Bangka Belitung

\begin{tabular}{|c|c|c|c|}
\hline No & Jenis Kelamin & Kuantitas & Persentase (\%) \\
\hline 1 & Pria & 20 & 60 \\
\hline 2 & Wanita & 30 & 100 \\
\hline \multicolumn{2}{|c|}{ Jumlah } & 50 & 60 \\
\hline
\end{tabular}

Sumber : Diolah dari Hasil Kuesioner

Berdasarkan Tabel 1 dapat diketahui bahwa jenis kelamin mahasiswa terbesar adalah wanita, dimana terdapat 30 orang atau $60 \%$ dari jumlah keseluruhan responden. Sedangkan jenis kelamin pria terdapat 20 orang atau $40 \%$ dari jumlah keseluruhan responden.

b. Usia responden

Karakteristik mahasiswa untuk selanjutnya dilihat dari usia responden. Pada umumnya usia responden yang diteliti adalah yang berusia antara 18-23 tahun. Hal itu dikarenakan objek penelitian ini lebih dititik beratkan pada mahasiswa yang mengerti sehingga kuisioner mampu terjawab dengan baik. Selain itu untuk mahasiswa yang berusia 36 tahun ke atas juga dapat diteliti sebagai mahasiswa pasca sarjana IAIN Syaikh Abdurrahman Siddik Bangka Belitung. Karakteristik responden berdasarkan usia dilihat pada Tabel 2.

Tabel 2. Karakteristik Responden Berdasarkan Usia Pada IAIN Syaikh Abdurahman Siddik Bangka Belitung

\begin{tabular}{|l|l|l|l|}
\hline No & Usia & Kuantitas & $\begin{array}{l}\text { Persentase } \\
(\%)\end{array}$ \\
\hline 1 & $18-23$ tahun & 32 & 64 \\
\hline 2 & $26-33$ tahun & 17 & 34 \\
\hline 3 & 36 tahun ke atas & 1 & 2 \\
\hline Jumlah & 60 & 100 \\
\hline
\end{tabular}

Sumber : Diolah dari Hasil Kuesioner 
Berdasarkan Tabel 2 dapat diketahui bahwa usia mahasiswa sebagian besar adalah diantara 12 sampai 23 tahun, dimana terdapat 32 orang atau $64 \%$ dari jumlah keseluruhan responden. Sedangkan usia 26-33 tahun terdapat 17 orang atau $34 \%$ dan 36 tahun ke atas terdapat 1 orang atau 2\% dari jumlah keseluruhan responden.

\section{HASIL DAN PEMBAHASAN}

\section{Hasil Penilaian Mutu dengan Balance Scorecard}

Hasil analisis data dijelaskan sebagai berikut.

\section{Perspektif Keuangan}

Perspektif keuangan diukur dengan pertumbuhan aset dan leverage seperti berikut.

a. Pertumbuhan Aset

$$
\begin{aligned}
& \text { GROWTH }=\text { Total Aktiva }{ }_{t}-\text { Total Aktiva } \text { A }_{t=1} \\
& \text { Total Aktiva }{ }_{t-1}
\end{aligned}
$$

$$
\text { GROWTH }=\underline{148.409 .046 .993-72.204 .789 .768}=\underline{76.204 .257 .225}=106 \%
$$

b. Leverage

Leverage yaitu rasio yang digunakan untuk mengukur sampai berapa jauh aktiva lembaga penyiaran dibiayai dengan hutang. Hasil perhitungan debt to total aset adalah:

Debt to Total Assets = Total Debt

Total Assets

Debt to Total Assets $2017=\underline{58.542 .585} \quad=0,08 \%$ 
2. Perspektif Pelanggan

1. Customer Care, yaitu:

Customer Retentio

$$
\begin{array}{rlrr}
= & \text { Jumlah Mahasiswa Lama } & \text { x } & 100 \% \\
=4.888 / 11.066=44,4 \% & & \text { Jumlah }
\end{array}
$$

Mahasiswa

Customer Acquisition $=$ Jumlah Mahasiswa Baru $\quad$ x 100\% $=6.188 / 11.066$ $=55,5 \%$

$$
\text { Jumlah Mahasiswa }
$$

3. Perspektif Proses Bisnis Internal

Pengukuran kinerja dengan perspektif bisnis internal diperoleh dengan penilaian mengajar dan atmosfir akademik dimana hasil responden atas variabel persepektif bisnis internal menjelaskan bahwa 75\% menyatakan baik sedangkan 25\% menyatakan cukup baik. Penilaian mahasiswa tentang kegunaan program dan kurikulum menjelaskan bahwa sebanyak 88\% mahasiswa menyatakan sesuai profesi dan karir masa depan. Berdasarkan kualitas lulusan juga dilihat dari masa studi menemukan bahwa kependidikan S-1 ditempuh rata-rata 4 tahun dengan IPK rata-rata 3.35.

4. Perspektif Proses pembelajaran dan pertumbuhan

Perspektif ini dijelasan dengan indikator kepuasan pegawai dan dosen dengan item kehadiran dosen yang pada umumnya sebanyak $87 \%$ dari seluruh jumlah kuliah, berdasarkan penilaian masing-masing indikator dijelaskan Tabel 3.

Tabel 3. Hasil Persepektf Pembelajaran dan Pertumbuhan

\begin{tabular}{|c|c|c|c|c|c|}
\hline Keterangan & $\begin{array}{c}\text { Proses } \\
\text { seleksi }\end{array}$ & $\begin{array}{c}\text { Kesempatan } \\
\text { pengembangan }\end{array}$ & $\begin{array}{c}\text { Sistem } \\
\text { penilaian }\end{array}$ & Kompensasi & $\begin{array}{c}\text { Sistem } \\
\text { pengembanga }\end{array}$ \\
\hline Dosen & 3,33 & 3,24 & 3,48 & 3,90 & 3,25 \\
\hline Karyawan & 3,33 & 3,24 & 3,41 & 3,56 & 3,50 \\
\hline
\end{tabular}

Sumber : Diolah dari Hasil Kuesioner 
Hasil persepektif pembelajaran dan pertumbuhan dijelaskan bahwa ratarata sudah memenuhi nilai skor yang baik, baik dari pengembangan diri, kompensasi, kinerja dan pengembangan karir.

Hasil-hasil pengukuran dari masing-masing perspektif dalam Balanced Scorecard, yaitu perspektif keuangan, perspektif pelanggan, perspektif proses bisnis internal serta perspektif pembelajaran dan pertumbuhan dapat mencerminkan gambaran umum dari IAIN Syaikh Abdurrahman Siddik Bangka Belitung. Setiap perguruan tinggi akan mencoba untuk mewujudkan apa yang menjadi tujuan mereka dalam kehidupan organisasinya, tidak terkecuali juga terjadi pada IAIN Syaikh Abdurrahman Siddik Bangka Belitung dimana mencoba untuk memperbaiki dan meningkatkan kinerja pelayanannya di semua unit usaha agar dapat meraih pelayanan yang baik dan memenuhi kepuasan mahasiswa dan pegawai secara keseluruhan. Jadi setiap komponen yang membantu terwujudnya tujuan perguruan tinggi sangat perlu untuk diperhatikan. Hal-hal yang mendukung kelancaran kinerja perguruan tinggi seperti empat perspektif dalam Balanced Scorecard, harus selalu dijaga dan ditingkatkan. Hasil analisis masingmasing perpsektif dijelaskan sebagai berikut.

a. Perspektif Keuangan

Perspektif keuangan memiliki 2 indikator yaitu pertumbuhan aset dan leverage keuangan. Perhitungan tersebut dimaksudkan untuk mengetahui keberhasilan perguruan tinggi dalam menjalankan kegiatan operasionalnya, sehingga dapat dinilai sampai sejauh mana perusahaan mencapai sasaran yang ditargetkan oleh perguruan tinggi.Perspektif keuangan merupakan aspek keuangan IAIN Syaikh Abdurrahman Siddik Bangka Belitung. yang dapat diukur melalui pertumbuhan aset dan leverage keuangan tahun 20172018, secara umum memperlihatkan kondisi kinerja yang baik untuk pertumbuhan aset dan leverage.

Tingkat pertumbuhan aset menunjukkan bahwa pada tahun 2017-2018 juga terjadi kecenderungan kenaikan aset. Hal itu menunjukkan bahwa aset IAIN Syaikh Abdurahman Siddik Bangka Belitung semakin tinggi. Tingkat leverage terjadi perkembangan yang fluktuatif. Hal itu dijelaskan bahwa 
hutang IAIN Syaikh Abdurrahman Siddik Bangka Belitung mampu dipenuhi oleh aset tersedia. Perkembangan kinerja keuangan tersebut menunjukkan bahwa kondisi keuangan perguruan tinggi dapat dikatakan mengalami peningkatan kinerja yang cukup baik. Meskipun perguruan tinggi tidak berorientasi pada bisnis yang bertujuan pada peningkatan keuntungan namun pada sisi biaya tidak dilakukan efisiensi hanya penggunaan biaya yang yang disesuaikan dengan dana anggaran dari pemerintah.

b. Perspektif pelanggan

Tolok ukur yang digunakan untuk menilai perpektif ini antara lain perspektif pelanggan. Dalam penelitian ini disebut perspektif pelanggan dapat diukur dengan Customer Retention, Customer Acquisition, dan Customer Value Proposition selama periode tahun 2017-2018. Pada perhitungan tingkat Customer Retention terlihat bahwa persentase akuisisi mahasiswa dan pegawai mengalami perkembangan yang fluktuatif, yaitu penambahan dan penurunan mahasiswa dan pegawai tahun 2017-2018 cenderung tidak meningkat bahkan stabil peningkatan dan penurunannya. Sedangkan Customer Acquisition terlihat bahwa persentase akuisisi mahasiswa mengalami peningkatan, yaitu penambahan mahasiswa tahun 2017-2018 diperoleh indeks mahasiswa IAIN Syaikh Abdurrahman Siddik Bangka Belitung yang cenderung naik.

c. Perspektif Proses Bisnis Internal

Perspektif proses bisnis internal memberikan informasi menyangkut proses internal perusahaan yang akan berdampak kepada kebaikan mahasiswa dan pegawai dan pencapaian tujuan finansial perguruan tinggi. Berdasarkan hasil penelitian menjelaskan bahwa aspek bisnis internal dapat ditingkatkan mutu pendidikan dengan cara:

Kurikulum didesain sesuai kebutuhan stakeholder dan dilakukan evaluasi secara berkala setiap empat tahun sekali Adanya proses monitoring dan evaluasi kurikulum akan memastikan apakah program pengajaran berjalan atau tidak serta mencegah preventif penyimpangan. 
i) Pengkajian dan pengembangan sistem dilaksanakan dengan disertai mutu pembelajaran serta penelitian dan pengabdian pada masyarakat.

ii) Adanya kebebasan akademik dengan seminar, kuliah, workshop, dan pembelajaran.

iii) Adanya kegiatan perencanaan dan pengalokasian dana dengan mekanisme rapat kerja dengan mengkombinasikan, mekanisme buttom up dan top down.

iv) Pembuatan laporan keuangan secara periodik dan diaudit oleh Badan Pemeriksa Keuangan (BPK).

v) Penetapan biaya pendidikan dan memberikan kebijakan keringanan berupa beasiswa kepada yang berpotensi secara akademik dan kurang mampu.

vi) Pengelolaan sarana dan prasarana sesuai dengan standar operasional prosedur (SOP) yang ada di perguruan tinggi seperti; laboratorium, sarana kelas, kebersihan, perpustakaan, jaringan internet, sarana administrasi pendukung lainnya.

Adanya upaya peningkatan pelayanan kinerja perbaikan dari tahun ke tahun dalam upaya peningkatan kinerja pelayanan kepada mahasiswa dan pegawai dan masyarakat. Meskipun mitra yang terjalin dengan IAIN Syaikh Abdurahman Siddik Bangka Belitung yaitu dengan perguruan tinggi lain, tokoh publik dan lain-lain.

d. Perspektif pertumbuhan dan pembelajaran

Perspektif pertumbuhan dan pembelajaran menggunakan diukur dengan pengembangan sumber daya, ketersediaan informasi, kepuasan internal dari pegawai dan dosen. Perspektif pertumbuhan dan pembelajaran difokuskan pada pengelolaan dan tanggung jawab perguruan tinggi. Berdasarkan hasil analisis menunjukkan bahwa perspektif pertumbuhan dan pembelajaran diupayakan pencapaian kepuasan pegawai dengan berbagai aktivitas untuk mencapai tujuan. Pertumbuhan dan pembelajaran organisasi 
yang baik melalui pengembangan studi lanjut, pelatihan, workshop dan seminar. Selain itu, kepuasan dalam bentuk kompensasi bagi pegawai dan dosen berupa tunjangan struktural, tunjangan fungsional dan tunjangantunjangan lain yang mendukung pegawai dan dosen IAIN Syaikh Abdurrahman Siddik Bangka Belitung.

\section{Kesimpulan}

Berdasarkan hasil penelitian dan pembahasan dijelaskan kesimpulan sebagai berikut: 1) berdasarkan perspektif keuangan menunjukkan bahwa pertumbuhan aset dan leverage menunjukkan adanya perkembangan yang meningkat selama tahun 2017-2018; 2) Berdasarkan pengukuran perspektif Pertumbuhan dan Pembelajaran (Learning and Growth), yaitu kepuasan mahasiswa, dosen dan pegawai diterima dan dirasakan sistem pengelolaan di IAIN Syaikh Abdurrahman Siddik Bangka Belitung sudah baik; 3) Berdasarkan pengukuran persepktif bisnis internal menunjukkan bahwa IAIN Syaikh Abdurahman Siddik Bangka Belitung telah menjalankan berbagai program pembenahan proses internal guna meningkatkan mutu lulusan.; 4) Berdasarkan perspektif pelanggan berupa Customer Retention, Customer Acquisition, dan Customer Value Proposition selama periode tahun 2017-2018. Pada perhitungan tingkat Customer Retention terlihat bahwa persentase akuisisi mahasiswa dan pegawai mengalami perkembangan yang fluktuatif dan cenderung baik.

Adapun saran yang peneliti sampaikan adalah hendaknya IAIN Syaikh Abdurrahman Siddik Bangka Belitung melakukan peningkatan di aspek keuangan dan non keuangan dengan memadukan kombinasi pengukuran kinerja yang seimbang, mempertahankan yang sudah baik dan meningkatkan yang masih perlu perbaikan. Selain itu pihak IAIN Syaikh Abdurrahman Siddik Bangka Belitung perlu melakukan pengukuran dari aspek landasan nilai Islami sesuai visi dan misi yang telah ditetapkan. 


\section{DAFTAR PUSTAKA}

Al-Hosaini, Fahmi Fadhl dan Sofian, Saudah. 2015. Balanced Scorecard Framework in Higher Education. International Review of Management and Marketing Vol. 5, No. 1

Anthony, Robert N. dan Govindarajan, Vijay. 2005. Buku 2 Management Control System. Jakarta. Salemba Empat.

Gaspersz, Vincent. 2014. Production Planning and Inventory Control, Jakarta:

Gramedia Pustaka Utama.Hamid Edy Suandy. 2013.Membangun Brand dan Trik Jitu Perguruan Tinggi Mandiri, Berkualitas Menuju World Class University. Seminar di Ballroom Hotel Sheraton Yogyakarta

Hamid Darmadi. 2013. Metode Penelitian Pendidikan dan Sosial. Bandung:

Ilyasin, Mukhammad dan Zamroni Zamroni. 2015. Balanced Scorecard: A Strategy for the Quality Improvement of Islamic Higher Education. Dinamika Jurnal Volume 2 No.1

Kaplan, Robert S. and D.P Norton. 2000. Balanced Scorecard: Menerapkan Strategi Menjadi Aksi. Alih Bahasa: Peter R, Yosi Pasla . Jakarta. Erlangga

Luis, Suwardi. 2010. Step by Step in Cascading Balanced.PT. Gramedia Pustaka Utama. Jakarta.

Mulyadi. 2015. Akuntansi Biaya, Edisi 5. Yogyakarta : Sekolah Tinggi Ilmu. Manajemen YKPN

Sugiyono, 2015, Metode Penelitian Kombinasi (Mix Methods). Bandung: Alfabeta. 